九州大学学術情報リポジトリ

Kyushu University Institutional Repository

\title{
A New Species Belonging to the Subgenus Euandrena of the Genus Andrena from Xinjiang Uygur, China with Notes on Nest Structure (Hymenoptera, Andrenidae)
}

Tadauchi, 0samu

Faculty of Agriculture, Kyushu University

Miyanaga, Ryoichi

Faculty of Life and Environmental Science, Shimane University

Dawut, Ahmatjan

Faculty of Agriculture, Kyushu University

https://doi.org/10.5109/2699

出版情報 : ESAKIA. 45，pp.9-17，2005-03-31. Entomological Laboratory，Faculty of Agriculture， Kyushu University

バージョン：

権利関係 : 
ESAKIA, (45): 9-17. March 31, 2005

\title{
A New Species Belonging to the Subgenus Euandrena of the Genus Andrena from Xinjiang Uygur, China with Notes on Nest Structure (Hymenoptera, Andrenidlae $)^{1,2), 3)}$
}

\author{
Osamu TADAUCHI \\ Entomological Laboratory, Faculty of Agriculture, Kyushu University, \\ Fukuoka, 812-8581 Japan \\ Ryoichi Miyanaga \\ Division of Environmental Biology, Faculty of Life and Environmental Science, \\ Shimane University, Nishikawazu, Matsue, 690-8504 Japan \\ and \\ Ahmatjan DAWUT \\ Entomological Laboratory, Faculty of Agriculture, Kyushu University, \\ Fukuoka, 812-8581 Japan
}

\begin{abstract}
A new species belonging to the subgenus Euandrena of the genus Andrena is described from Xinjiang Uygur, China. It is the species most associated with the semi-desert flowers of Chondrilla brevinotris (Compositae) in the Dzungaria Basin. The nest structure of the species is detailed.

Key words: Hymenoptera, Andrenidae, Andrena, Euandrena, new species, China, nest structure, pollination of desert plant.
\end{abstract}

\section{Introduction}

We have made field surveys on wild bees in northwestern China and Central Asia since 2000 to accumulate information on pollination for combating desertification and improving

1) Contribution from the Entomological Laboratory, Faculty of Agriculture, Kyushu University, Fukuoka (Ser. 6, No. 8).

2) This work was supported by a Grant-in-Aid for Scientific Research (B) (2) from the Japan Society for the Promotion of Science (No. 14405025) (Head investigator: O. Tadauchi).

3) Results from the China-Japan Co-operative Study on "Studies on Systematics, Evolution and Biogeography of Asian Andrena (Hym., Apoidea, Andrenidae)" No. 16. 
planting campaigns. One of the aims of this research is to discover useful wild bees which pollinate semi-desert plants and to study their nesting and pollinating biology. In late August, 2002 we conducted an exploration in the Dzungaria Basin, north of Xinjiang Uygur Autonomous Region, China. In the expedition we found an andrenid bee which pollinates Chondrilla brevinotris in Jeminay, Altay Province, situated $1,300 \mathrm{~m}$ above sea level, in a northwesterly position within the Dzungaria Basin, and near a national border with Kazakhstan. This member of the Compositae is one of the representative desert plants in China. We found the nesting site of the bee and studied its nest structure. In the present study we recognize this andrenid bee as new to science and describe this new species with details of its nest structure.

The holotype will be preserved in the Institute of Zoology, Chinese Academy of Sciences, Beijing, China, and the paratypes will be deposited in the above institute and the Entomological Laboratory of Kyushu University, Fukuoka, Japan.

\section{Taxonomy}

Andrena (Euandrena) almas n. sp.

(Figs. 1: A-E, 2: A-E, 3: A-E)

Female: BL 9.0-9.6 mm, WL 8.1-8.6 mm ( $\mathrm{n}=5)$.

Color: Flagellum reddish brown beneath; mandible with apical third reddened; wing membranes subhyaline, veins and pterostigma yellowish; all tarsi and hind tibia ferruginous, tibial spurs yellowish; metasomal terga reddened in part, tergum 2 mostly reddened, posterior depressions of metasomal terga reddish brown.

Pubescence: Hairs on head and thorax yellow not mixed with brown; those on clypeus 200 $\mu$; those on antennal area long and dense; those on vertex $200 \mu$; facial fovea bright yellow. Hairs on thorax moderately dense; those on mesoscutum $300-400 \mu$; those on scutellum and metanotum longer; those on mesepisternum $400 \mu$; propodeal corbicula moderately developed, with internal sparse branched hairs; trochanteral floccus perfect, yellowish; femoral floccus dense; tibial scopal hairs long, partly branched, yellow. Hairs on metasomal terga scanty, tergum 1 with elect long yellowish hairs; terga 2-4 with short yellowish hairs, terga 2-4 with yellowish hair bands, broadly interrupted on terga 2-3; caudal fimbria golden; sterna 2-5 with long, sparse yellowish subapical fimbriae.

Structure: Head: $\mathrm{HL} / \mathrm{HW}=0.86$. HW: $\mathrm{MsW}: \mathrm{MtW}=7.1:$ 6.8: 6.9. Vertex shagreened. OOD: POD: $\mathrm{OCD}=1.1: 1.0: 0.7$. FL1 > FL2+3, FL2 < FL3 which is slightly broader than long, intermediate segments slightly broader than long. Eyes with inner margins subparalleled. Facial fovea narrow, extending below to a line at lower margin of antennal fossae, $F V L=1.0 \mathrm{~mm}$, $\mathrm{FVW}=0.3 \mathrm{~mm}$. Supraclypeal area and face above antennal fossae with fine longitudinal 

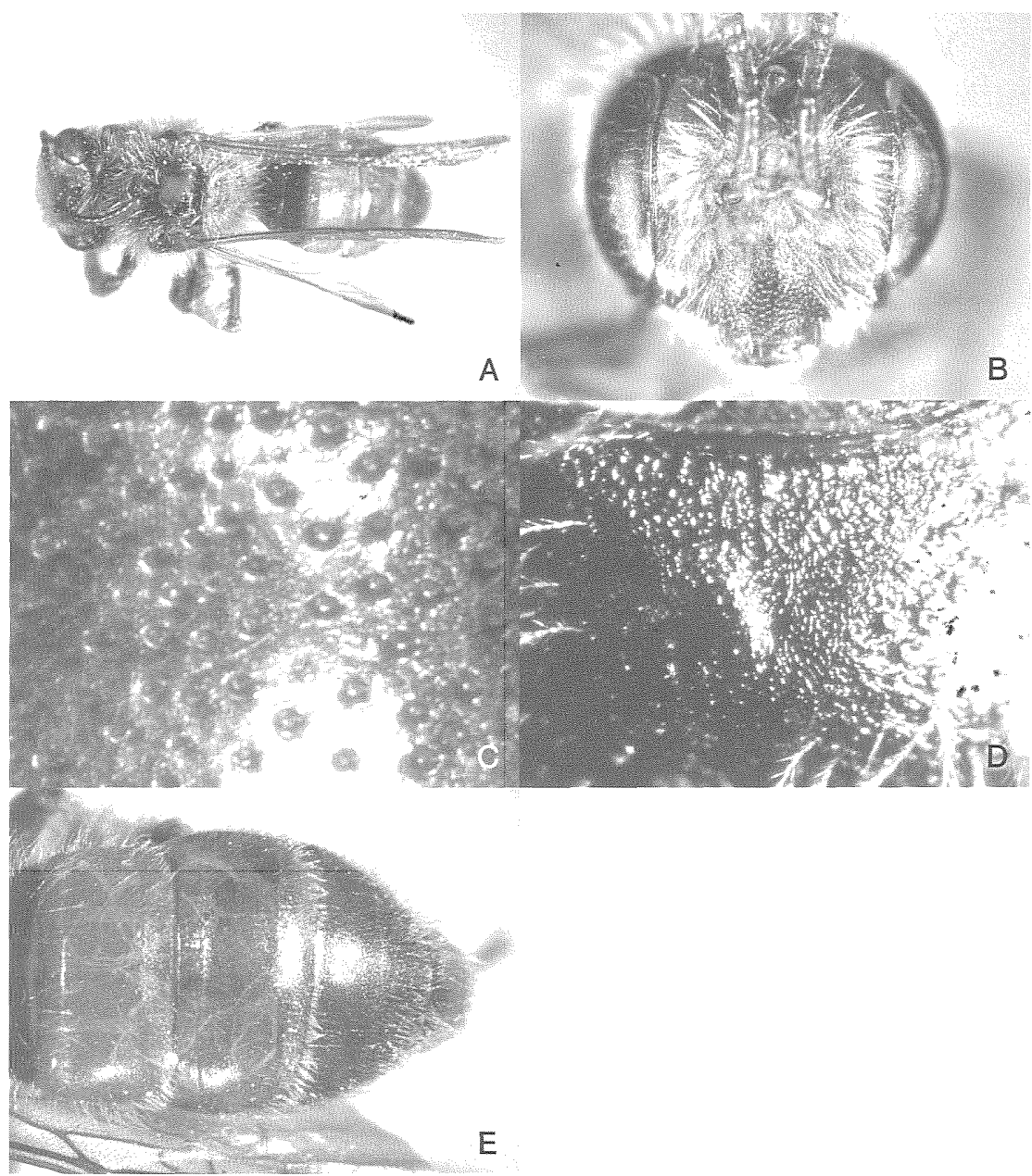

Fig. 1: A-E. Andrena (Euandrena) almas n. sp., female. A. general habitus; B: head in frontal view; $\mathrm{C}$ : mesoscutum; D: propodeum; $\mathrm{E}$ : metasomal terga.

rugulae and coarse interrugal PP. Facial quadrangle nearly as broad as long (about 5.0: 4.8). Clypeus moderately convex, weakly tessellate, with a narrow median tessellate impunctate line, surface with PPø20 $\mu$, IS $=0.5-1, \mathrm{CPL}=0.8 \mathrm{~mm}$. Process of labrum transverse, entire or weakly emarginate apically. Lower paraocular area weakly tessellate and crowdedly punctate. Malar space linear. Genal area broader than eye, GW: $\mathrm{EW}=1.8: 1.3$, surface finely tessellate, narrowly shiny with obscure minute PP. Mesosoma: Pronotum weakly tessellate with obscure PP. Mesoscutum weakly tessellate anteriorly, smooth and shiny posteromedially, surface with PPø10 $\mu, \mathrm{IS}=1-2$. Scutellum smooth and shiny with PPø10-15 $\mu, \mathrm{IS}=1-2$. Propodeal enclosure ill defined, weakly rugose at basal $1 / 4$, shagreened apically; dorsal face of propodeum 
dulled by coarse punctation. Mesepisternum roughened anteriorly, densely tessellate posteriorly. Vein $1 \mathrm{st} m$-cu meeting second submarginal cell at middle or beyond of cell. Metasoma: Metasomal terga smooth and shiny with microscopical PPø10 $\mu, \mathrm{IS}=1-3$; posterior depressions of terga not well indicated; pygidial plate $\mathrm{V}$-shaped, without raised internal triangular area. Sterna 2-5 finely tessellate, with minute PP.

Male: BL 8.1-8.4 mm, WL 7.3-8.0 mm $(\mathrm{n}=2)$.

Color: Flagellum chocolate beneath; mandible with apical third reddened; wing membranes subhyaline, moderately brown, veins and pterostigma brown; all tarsi and hind tibia ferruginous; tibial spurs reddish yellow; metasomal terga partly ferruginous; posterior depressions of metasomal terga reddish brown.

Pubescence: Hairs on head and thorax pale yellowish, not mixed with brown on vertex and mesoscutum. Hairs on metasomal terga short and sparse, pale yellowish; terga 2-5 with obscure white hair bands, interrupted on terga 2-3; sterna $2-5$ with well-formed yellowish subapical fimbriae.

Structure: Head: HL/HW=0.84. HW: MsW: $\mathrm{MtW}=7.0: 6.5: 6.2$. Vertex roughened by coarse minute PP. OOD: POD: $\mathrm{OCD}=1.2: 1.1: 0.8$. FL1 > FL2, FL2 < FL3, which is longer than broad. Eyes with inner margins subparalleled. Supraclypeal area and face above antennal fossae sculptured as in female. Facial quadrangle quadrate (about 4.8: 4.6). Clypeus moderately convex, smooth and shiny, surface with $P P ø 20 \mu$, IS $=0.5-1$, without a median impunctate line, $\mathrm{CPL}=0.7 \mathrm{~mm}$. Process of labrum small, weakly emarginate apically, surface smooth and shiny. Mandibles decussate. Lower paraocular area as in female. Malar space linear. Genal area as slightly broader than eye, $\mathrm{GW}: \mathrm{EW}=1.6: 1.5$, surface broadly shagreened. Mesosoma: Mesoscutum smooth and shiny with weak PPø15 $\mu, \mathrm{IS}=1$. Propodeal enclosure rugose at basal 1/4, tessellate apically. Metasoma: Metasomal terga smooth and shiny, minutely punctate on terga $1-5, \mathrm{PP} \varnothing 10 \mu, \mathrm{IS}=1-2$; posterior depressions of terga not well indicated. Sterna 2-5 smooth and, weakly and sparsely punctate as in terga 2-5; Genitalia and associated structures illustrated in Fig. 3: A-E.

Type material: Holotype female: East of Jeminay, 1,300 m, Altay Prov., Xinjiang Uygur Auton. Region, China, 28. viii. 2002 (O. Tadauchi); Paratypes: CHINA: Xinjiang Uygur Auton. Region: same locality and date as the holotype: 19 females and 2 males (O. Tadauchi), 27 females and 1 male (R. Murao); 15 females (A. Dawut).

Remarks: This species is similar to Andrena opercula $\mathrm{Wu}$ in female in having the metasomal terga reddened. The female can be separated from that of opercula by all the tarsi and hind tibia ferruginous, the vertex without brown hairs, the caudal fimbria golden, the process of labrum transverse, and the mesoscutum smoother and shiner.

Distribution: China (Xinjiang Uygur Auton. Region).

Floral association: Chondrilla brevinotris (Compositae).

Flight records: Female: late August; male: late August. 


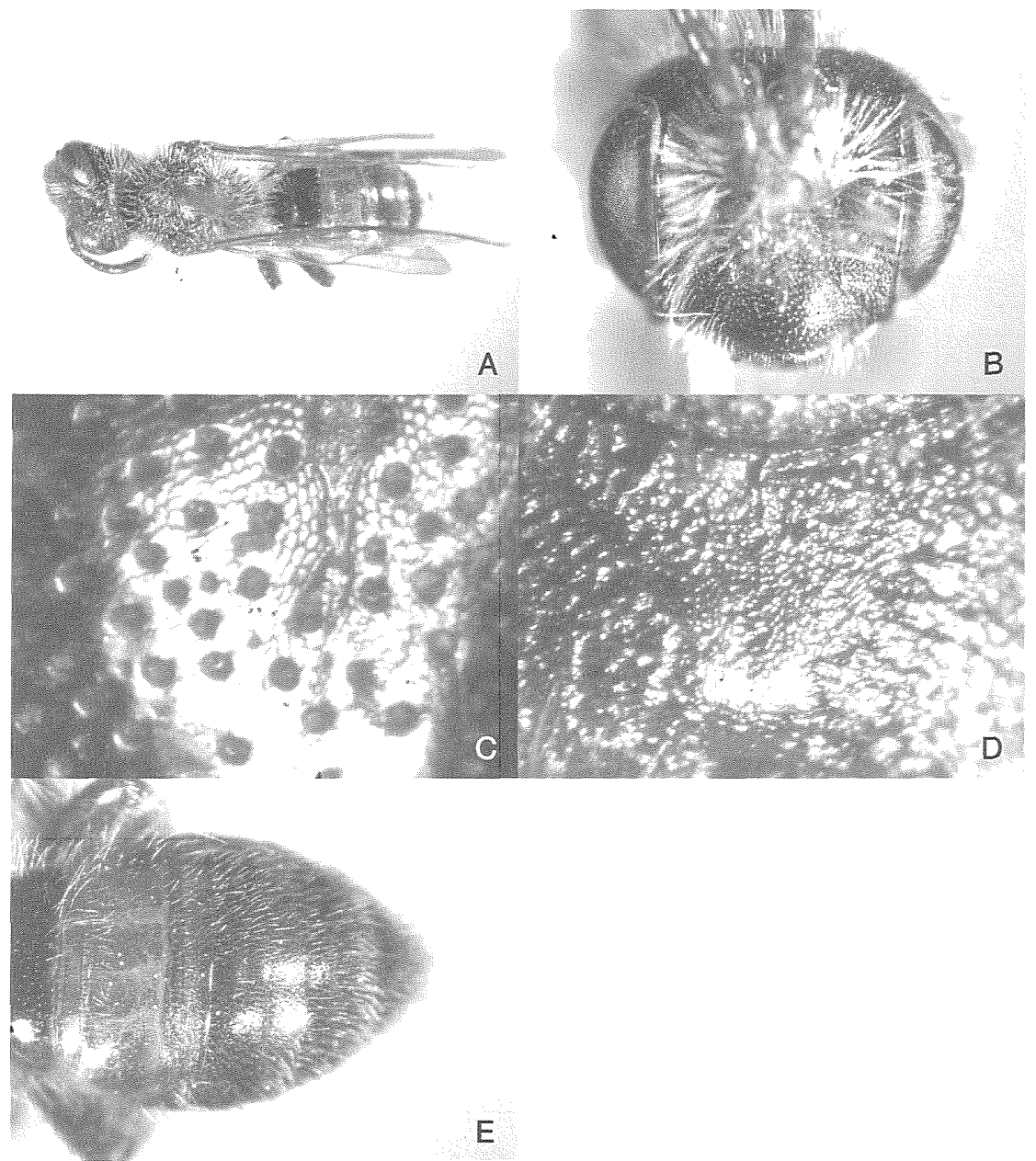

Fig. 2: A-E. Andrena (Euandrena) almas n. sp., male. A. general habitus; B: head in frontal view; C: mesoscutum; D: propodeum; E: metasomal terga.

Etymology: The specific name is derived from an Uygur word, almas meaning jewely.

\section{Biology}

\section{Nest Structure}

A large aggregation of the nests was discovered on August 28, 2002, just east of Jeminay, $47^{\circ} 17^{\prime} \mathrm{N}$; $86^{\circ} 1^{\prime} \mathrm{E}$, Xinjiang Uygur Autonomous Region, China, at an elevation of $1300 \mathrm{~m}$. Patches of dense nest aggregations were found at the bottom of a near-vertical road cut towering in places to heights of $10 \mathrm{~m}$, along a trunk road between Jeminay and Altay (Fig. 5). 

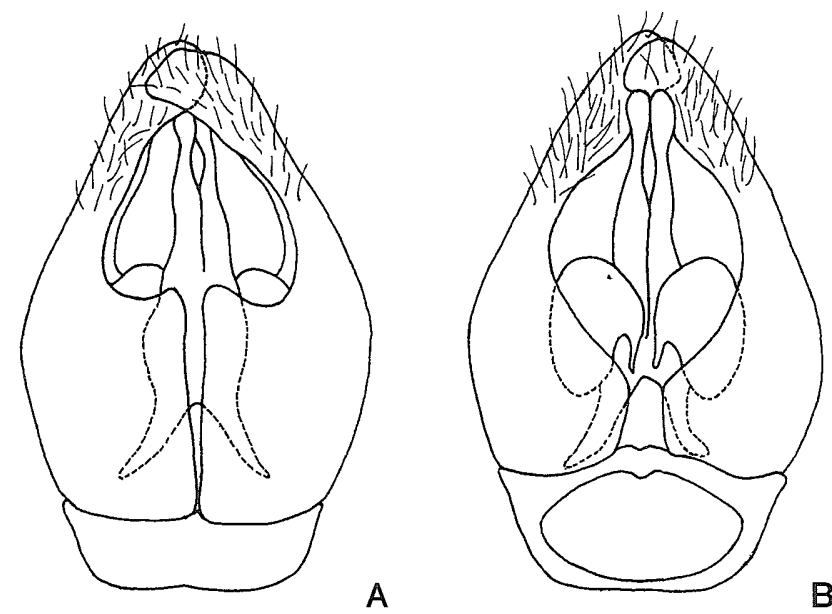

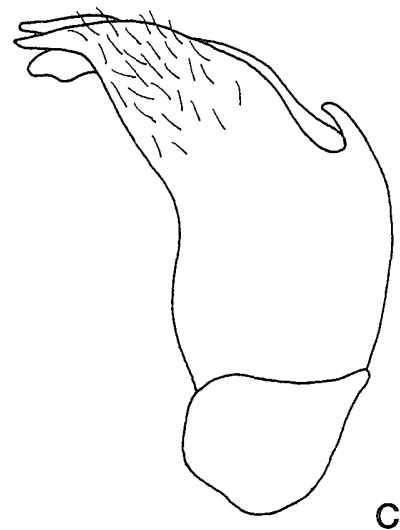

C
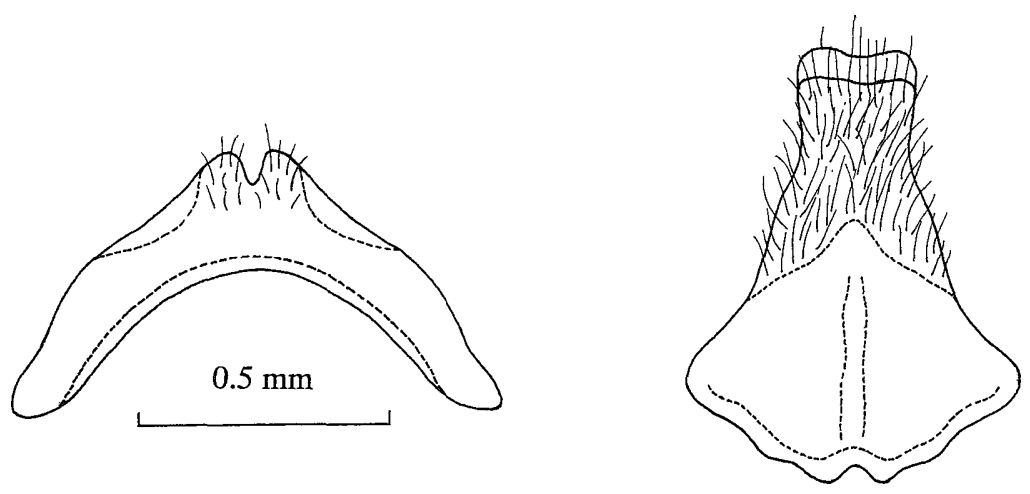

D

$\mathbf{E}$

Fig. 3: A-E. Andrena (Euandrena) almas n. sp., male. A. Genital capsule and subgenital sterna. A: dorsal view of genital capsule; B: ventral view of the same; C: lateral view of the same; D: metasomal sternum $7 ; \mathrm{E}$ : metasomal sternum 8 .

The bottom of the slope was composed of a layer of clay with sand admixture in some parts. Nests were concentrated at or near this bottom location, in an area where the clay soil was somewhat moist just below the surface and without pebbles and rocks. Several other halictine species nested at this locality.

Jeminay has a dry, semi-arid climate. The newly discovered andrenid bee species was active at the time of the expedition, but only females were seen flying over the nesting area and carrying pollen. Some species of flowering plants were found near the nesting area, but the great majority of foraging females were returning with pollen loads of Chondrilla brevinotris Fisch. et Mey (Fig. 6). Active nests were located by following the movements of returning females. Since nests were closely aggregated (entrances sometimes only $1 \mathrm{~cm}$ apart), only 


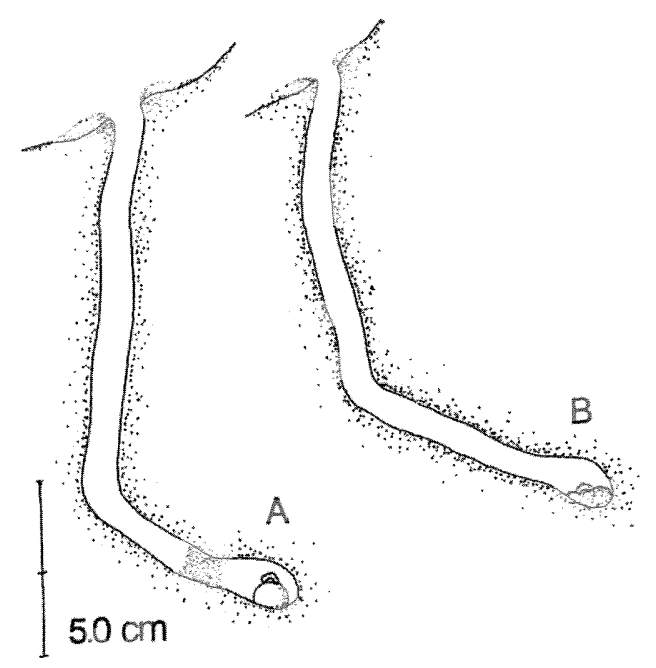

Fig. 4. Nest structure of Andrena (Euandrena) almas n. sp.

two of more than 10 active nests were completely excavated. The nests consist of simple burrows extending into the clay soil to a depth of 14 to $20 \mathrm{~cm}$ (Fig. 4). The entrances were 5.5 to $6.0 \mathrm{~mm}$ in diameter, without any conspicuous constructions. Some entrances had a tumulus, a pile of the soil removed from the nest. The tumuli were usually arranged in a concentric manner around the nest entrances, but they were occasionally piled on the lower side of an entrance on a slope. No special enlargement was seen immediately below nest entrances.

The inner walls of the burrow were more or less smooth, and they were not coated with any detectable secretion. The diameters of the entire length of burrows were approximately the same as those of the entrance. The burrows were more of less perpendicular to the level of a cell where it turns to one side, and may be as much as $90^{\circ}$ from the vertical plane (Fig. 4). The cells were made in the damp clay soil, and were situated at the ends of the burrows. It appears that each nest has only one cell in this species.

Brood cells slightly declined downward, at a $30-40^{\circ}$ angle from the horizontal, and their shape was similar to those of the other andrenid bees. They are heteromorphic, being of an elongated oval shape with a flat floor. The size of cells was as follows: $13-15 \mathrm{~mm}$ in length and $6.0-7.0 \mathrm{~mm}$ at the widest part for cells. The inner cell wall was smooth and coated, except for the neck part, which was $4.5-5.0 \mathrm{~mm}$ in diameter. The contents of cells varied from eggs to large larvae, but neither pupae nor prepupae were found. The shape of pollen balls were round, 3.6-4.1 $\mathrm{mm}$ in diameter and eggs were laid on top of it (Fig. 7). Cells contained an egg were sealed with plug of loose soil. When nests were excavated, one cell was open, being provisioned and contained pollen mass, as yet not formed into the pollen ball (Fig. 8).

Most soil nesting bees construct nests containing several brood cells which are connected 


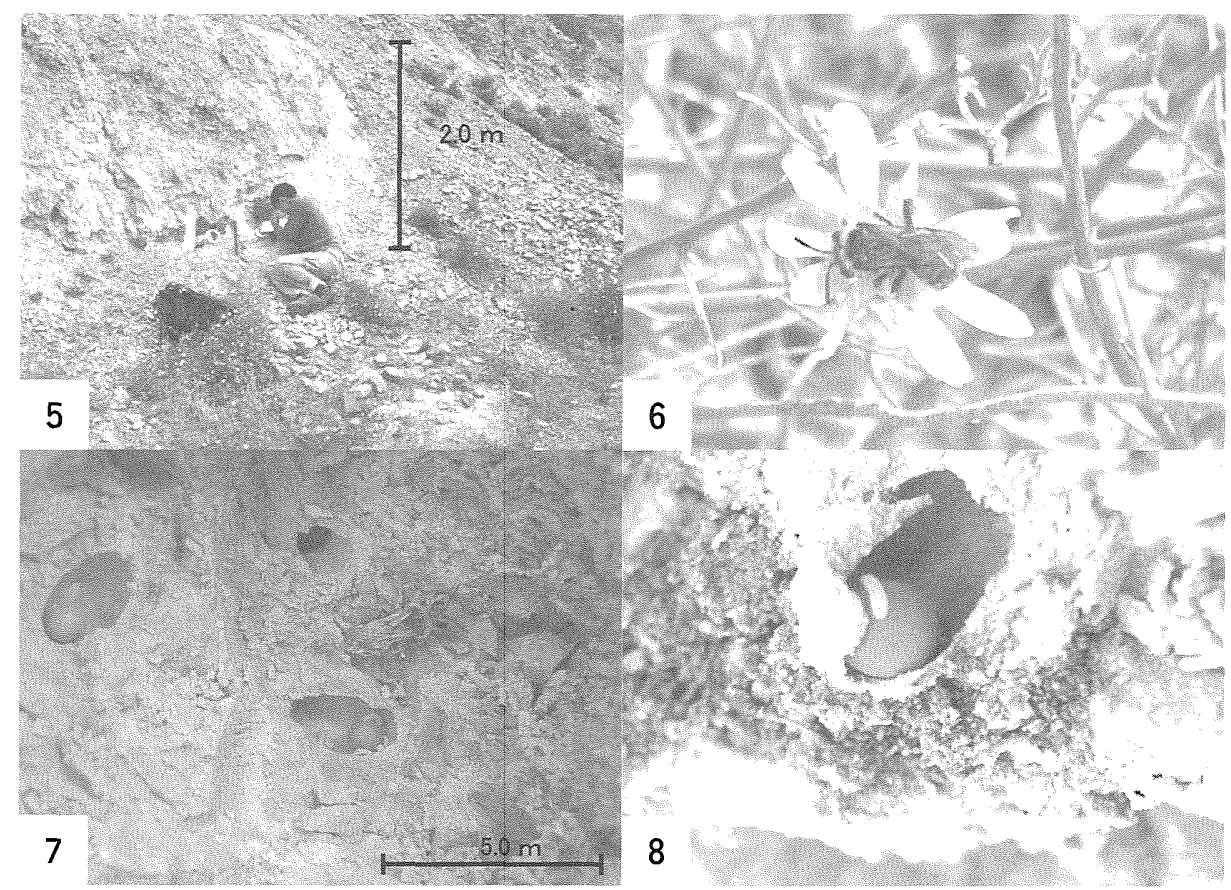

Figs. 5-8. 5: Nest site of Andrena (Euandrena) almas n. sp. along a trunk road;

6: Foraging on Chondrilla brevinotri; 7: Brood cell with pollen ball and egg;

8: Brood cell with some pollen.

with the main burrow by mean of laterals. The unicellular nest, consisting of a single burrow leading to a brood cell, is frequently found in wasps (Maeta, 2000). In andrenid bees, such a nest is known only in Perdita maculigera maculipennis which excavates nests in loose sand (Michener and Ordway, 1963). Howeer, Michener (2000) suggested that observational error might have been involved in the description of the nest in P. maculigera maculipennis, because since it is very difficult to find and follow the tiny burrows in sand. To avoid such an error, we carefully excavated two nests of the new Andrena species and did not detect any burrows in these nests.

\section{Acknowledgments}

We are grateful to Prof. D-y. Wang of Xinjiang Agricultural University, Urumuqi, Prof. S. Ikudome of Kagoshima Womens' Junior College, Kagoshima, Mr. R. Murao of Kyushu University, Fukuoka and Dr. Niu of the Institute of Zoology, Chinese Academy of Sciences, Beijing for their help during our field survey, and Prof. D-w. Huang and Prof. Y-r. Wu of the Institute of Zoology, Chinese Academy of Sciences, Beijing for their various support during our project. 


\section{References}

Gusenleitner, F. M. Schwarz, 2002. Weltweite Checkliste der Bienengattung Andrena mit Bemerkungen und Erganzungen $\mathrm{zu}$ paläarktichen Arten (Hymenoptera, Apidae, Andrenidae, Andrena). Entomofauna, suppl. 12: 1-1280.

Maeta, Y., 2000. [Utsugi-himehanabachi Andrena prostomias, Its Biology and Conservation]. Kaiyusha, Tokyo, 198 pp.

Michener, C. D. 2000. The Bees of the World. Johns Hopkins Univ. Press, Baltimore \& London.

Michener, C. D. \& E. Ordway., 1963. The life history of Perdita maculigera maculipennis (Hymenoptera: Andrenidae). J. Kansas entomol. Soc., 36: 34-45.

Osytshnjuk, A. Z., 1977. Bees-Andrenidae. Fauna Ukraini, 12 (5) : 1-328. (In Ukrainean.)

Schmid-Egger, C. \& E. Scheuchl, 1997. Illustrierte Bestimmungstabellen der Wildbienen Deutschlands und Österreichs unter Berücksichtigung der Arten der Schweiz. Band III: Andrenidae. 180 pp., Eigenverlag, Velden/Vils. 


$$
\text { ' }
$$

